[Article]

\title{
新型耐甲醇氧还原电催化剂——氮掺杂中空碳微球@铂纳米 粒子复合材料
}

\author{
田春霞 杨军帅 李 丽 张小华 陈金华 ${ }^{*}$ \\ (湖南大学化学化工学院, 化学生物传感与计量学国家重点实验室, 长沙 410082)
}

\begin{abstract}
摘要: 通过模板法制备了一种新型耐甲醇氧还原电催化剂——氮掺杂中空碳微球@铂纳米粒子复合材料 (HNCMS@Pt NPs)。首先, 将铂纳米粒子负载于氨基化二氧化硅微球上, 获得 Pt NPs/SiO 2 复合材料。然后 通过多巴胺自聚合反应在 $\mathrm{Pt} \mathrm{NPs} / \mathrm{SiO}_{2}$ 复合材料上包裹聚多巴胺 (PDA)膜, 将其在氮气气氛中直接进行碳化处 理并通过氢氟酸溶液刻蚀去除 $\mathrm{SiO}_{2}$, 获得了内嵌有 Pt NPs 的氮掺杂中空碳微球, 标记为 HNCMS@Pt NPs 复合材料。采用扫描电子显微镜、透射电子显微镜、X 射线衍射仪、拉曼光谱仪、比表面积分析仪和 $X$ 射线 光电子能谱仪对HNCMS@Pt NPs 复合材料的形貌和结构进行了表征。采用循环伏安法和线性扫描伏安法研 究了HNCMS@Pt NPs 复合材料的电催化氧还原性能。结果表明: HNCMS@Pt NPs 催化剂的Pt 载量高达 $11.9 \%$ ( $w$, 质量分数), 对氧还原反应具有高电催化活性、高稳定性和优良的抗甲醇性能, 是一种具有应用 潜力的直接甲醇燃料电池(DMFCs)阴极电催化剂。
\end{abstract}

关键词: Pt 纳米粒子; 氮掺杂; 空心碳微球; 氧还原反应; 抗甲醇

中图分类号: 0646; 0643

\section{New Methanol-Tolerant Oxygen Reduction Electrocatalyst_-Nitrogen- Doped Hollow Carbon Microspheres@Platinum Nanoparticles Hybrids}

\author{
TIAN Chun-Xia YANG Jun-Shuai LI Li ZHANG Xiao-Hua CHEN Jin-Hua* \\ (State Key Laboratory of Chemo/Biosensing and Chemometrics, College of Chemistry and Chemical Engineering, \\ Hunan University, Changsha 410082, P. R. China)
}

\begin{abstract}
A new methanol-tolerant oxygen reduction electrocatalyst, nitrogen-doped hollow carbon microspheres@platinum nanoparticles hybrids (HNCMS@Pt NPs), has been synthesized by a facile template route. In brief, $\mathrm{Pt} \mathrm{NPs}$ were loaded on the surface of $\mathrm{NH}_{2}$-functionalized $\mathrm{SiO}_{2}$ microspheres $\left(\mathrm{Pt} \mathrm{NPs} / \mathrm{SiO}_{2}\right)$. Then, the $\mathrm{Pt} \mathrm{NPs} / \mathrm{SiO}_{2}$ hybrids were wrapped by polydopamine (PDA) film. After direct carbonization of PDA-wrapped $\mathrm{Pt} \mathrm{NPs} / \mathrm{SiO}_{2}$ hybrids under a nitrogen atmosphere and further treatment in a hydrofluoric acid solution, Pt NPs embedded within nitrogen-doped hollow carbon microsphere (HNCMS) were obtained and labeled as HNCMS@Pt NPs. Scanning electron microscopy, transmission electron microscopy, X-ray diffraction, Raman spectroscopy, specific surface area analysis, and X-ray photoelectron spectroscopy were used to characterize the HNCMS@Pt NPs hybrids. The electrochemical properties of the HNCMS@Pt NPs hybrids for oxygen reduction reaction have also been investigated by cyclic voltammetry and linear sweep voltammetry. The results show that the Pt loading mass in the HNCMS@Pt NPs hybrids is up to $11.9 \%$ (w, mass fraction). Furthermore, the as-prepared HNCMS@Pt NPs catalyst exhibits good electrocatalytic activity, high stability, and excellent methanol-tolerance toward oxygen reduction reactions, implying potential applications in practical direct
\end{abstract}

Received: January 15, 2016; Revised: March 11, 2016; Published on Web: March 11, 2016.

*Corresponding author. Email: chenjinhua@hnu.edu.cn; Tel: +86-731-88821961; Fax: +86-731-88821848.

The project was supported by the Program for Changjiang Scholars and Innovative Research Team in University, China (IRT1238) and National Natural Science Foundation of China (21275041, J1210040, J1103312).

长江学者和创新团队发展计划(IRT1238)及国家自然科学基金(21275041, J1210040, J1103312)资助项目

(c) Editorial office of Acta Physico-Chimica Sinica 
methanol fuel cells (DMFCs) as methanol-tolerant cathodic catalysts.

Key Words: Pt nanoparticle; Nitrogen-doping; Hollow carbon microsphere; Oxygen-reduction reaction; Methanol-tolerance

\section{Introduction}

Direct methanol fuel cells (DMFCs) have attracted great attention due to their high power density, low operating temperature, low emission, and potential applications in automotive and portable power sources ${ }^{1}$. Up to now, platinum and platinum-based catalysts are most common catalysts in DMFCs. These catalysts show good catalytic performance both in anodic methanol oxidation reaction (MOR) and cathodic oxygen reduction reaction $(\mathrm{ORR})^{2-6}$. However, there are still several factors to hinder the widespread use of DMFCs, including high cost resulting from progressive increase of Pt price, sluggish kinetics and poor durability of both anodic and cathodic electrocatalysts, and methanol crossover from anode to cathode through the proton exchange membranes ${ }^{7}$. Among them, methanol crossover would result in that oxygen-reduction and methanol-oxidation reactions occur simultaneously, which causes a negative shift in the cathodic potential and a significant decrease in the performance and durability of the DMFCs. Methanol crossover becomes one of the main technical obstacles to the DMFC commercialization ${ }^{8}$.

In order to solve this problem (methanol crossover), it was reported that ORR selective electrocatalysts that were tolerant to methanol oxidation were one of the most useful strategies. There were many Pt-free cathodic catalysts, such as palladium-based materials ${ }^{9}$, ruthenium-based chalcogenides ${ }^{10}$, and transition-metal macrocycles with $\mathrm{N}$-based ligands ${ }^{11}$ to be developed. These catalysts showed good methanol-tolerant capability, but very lower activity and/or inferior long-term stability under operating conditions in comparison with Pt-based catalysts. Therefore, Pt-based catalysts are still considered as the efficient candidates to be used as the DMFC cathodic catalysts. Recently, it was reported that Pt NPs encapsulated in mesoporous carbons had good methanol tolerance and long-term stability. For example, Wen et al. ${ }^{12}$ reported a facile template route to the in-situ entrapment of core/ shell $\mathrm{Pt} / \mathrm{C}$ nanoparticles into the nanochannels of mesoporous carbons with uniform mesopores of about $3.5 \mathrm{~nm}$. Wu et al. ${ }^{13}$ prepared platinum@graphitic carbon (Pt@GC) composites with a relative small pore size about $3.6 \mathrm{~nm}$ by a chemical vapor deposition (CVD) method. Guo et al. ${ }^{14}$ directly carbonized zeolitic imidazolate framework (ZIF-8) with the encapsulated Pt NPs. All these catalysts showed high catalytic activity, good stability and good methanol tolerance for ORR. Unfortunately, a major limiting factor for the practical application of these catalysts is the low Pt content. Because of the small-size mesoporous, Pt NPs are hard to enter the nanochannel of mesoporous carbon. These give rise to most of methanol-tolerant oxygen reduction electrocatalysts with low Pt concents of $2 \%-5 \%$ ( $w$, mass fraction $)^{13,14}$.

On the other hand, due to the specific structure (hollow cores and carbon shells) and excellent characteristics of nitrogen doping,
$\mathrm{N}$-doped hollow carbon microspheres (HNCMSs), are received more and more attention in fuel cells, sensors, drug delivery, lithium ion batteries, active material encapsulation, hydrogen storage and so on ${ }^{15}$. As the catalyst support, most efforts were devoted to the dispersion of metal nanoparticles on the surface of the HNCMSs ${ }^{16,17}$. There are no works addressed on the dispersing Pt NPs on the inner surface of the HNCMSs to improve the methanol-tolerant property of the electrocatalysts in ORR process.

Here, taking $\mathrm{NH}_{2}$-functionalized $\mathrm{SiO}_{2}$ microspheres as the hard templates, we developed a new methanol-tolerant electrocatalyst (HNCMS@Pt NPs) which had mesoporous N-doped carbon shell and hollow structure, and Pt NPs loaded on the inner surface of the HNCMSs (Scheme 1). It exhibited superior performance as a methanol-tolerant ORR catalyst and Pt content was up to $11.9 \%$ (w), implying the potential application in practical DMFCs as the methanol-tolerant cathodic catalysts.

\section{Experimental}

\subsection{Materials}

The commercial catalyst $(20 \%(w)$ E-TEK Pt/C) was purchased from De Nora Elettodi Co. Ltd. (New Jersey, USA). $\mathrm{SiO}_{2}(500 \mathrm{~nm}$ in diameter) was obtained from Alfa Aesar (USA). Tris(hydroxymethyl)aminomethane (TRIS) was obtained from SigmaAldrich Co. Ltd. (USA). Dopamine (DA), cetyltrimethyl ammonium bromide (CTAB), 3-aminopropyltrimethoxysilane (APTES), $\mathrm{NH}_{4} \mathrm{~F}, \mathrm{HF}$, and $\mathrm{H}_{2} \mathrm{PtCl}_{6}$ were purchased from Sinopharm Chemical Reagent Co. Ltd. (China). All chemicals were of analytical grade and used as received. All aqueous solutions were prepared with ultrapure water $(>18 \mathrm{M} \Omega \cdot \mathrm{cm})$ obtained from a Millipore system

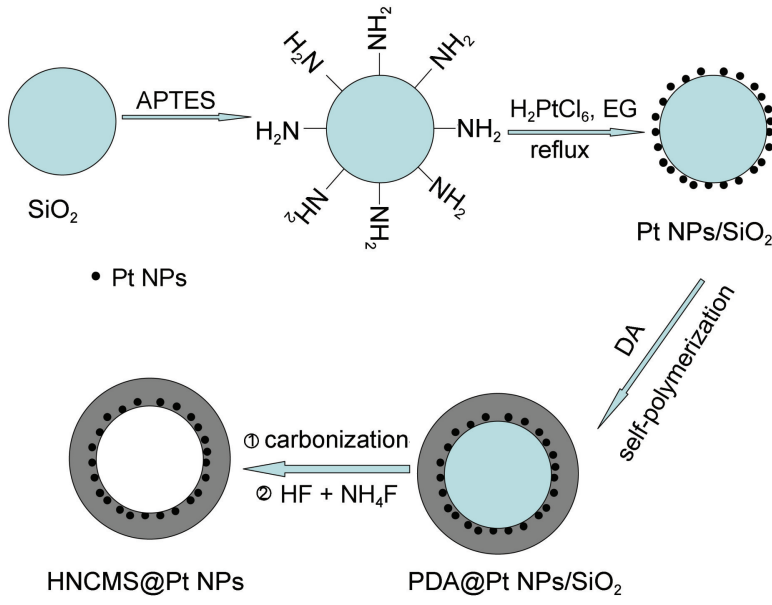

Scheme 1 Schematic illustration of the preparation of HNCMS@Pt NPs

APTES: 3-aminopropyltrimethoxysilane; EG: ethylene glycol; DA: dopamine; PDA: polydopamine 
(Millipore Corp., Bedford, MA, USA)

\subsection{Synthesis of Pt NPs/SiO ${ }_{2}$ and HNCMS@Pt NPs}

$\mathrm{SiO}_{2}$ particles $(1 \mathrm{~g}$, about $500 \mathrm{~nm}$ ) were dispersed into $100 \mathrm{~mL}$ dry toluene. 3-Aminopropyltrimethoxysilane (APTES, $10 \mathrm{~mL}$ ) was added to the above $\mathrm{SiO}_{2}$ suspension under stirring and the mixture was refluxed for $8 \mathrm{~h}$ at $100^{\circ} \mathrm{C}$ under nitrogen atmosphere. $\mathrm{NH}_{2}$-modified $\mathrm{SiO}_{2}\left(\mathrm{SiO}_{2}-\mathrm{NH}_{2}\right)$ were obtained by centrifugating at $10000 \mathrm{r} \cdot \mathrm{min}^{-1}$, washing with ethanol and drying under vacuum at $60{ }^{\circ} \mathrm{C} .200 \mathrm{mg} \mathrm{SiO}{ }_{2}-\mathrm{NH}_{2}$ particles were re-dispersed in $40 \mathrm{~mL}$ ethylene glycol (EG) with ultrasonication. $3.2 \mathrm{~mL} \mathrm{H}_{2} \mathrm{PtCl}_{6}(19.3$ $\left.\mathrm{mmol} \cdot \mathrm{L}^{-1}\right)$ aqueous solution and $54 \mathrm{mg} \mathrm{CTAB}$ were addeded to $30 \mathrm{~mL}$ ethylene glycol with ultrasonication. Then, these two kinds of solutions were mixed with ultrasonication for $0.5 \mathrm{~h}$ and refluxed for $3 \mathrm{~h}$ at $150{ }^{\circ} \mathrm{C}$. The product was obtained by centrifugating, washing, and drying as stated above, and labeled as $\mathrm{Pt} \mathrm{NPs} / \mathrm{SiO}_{2}$. After that, $400 \mathrm{mg} \mathrm{Pt} \mathrm{NPs} / \mathrm{SiO}_{2}$ was dispersed in $100 \mathrm{~mL} 50 \mathrm{mmol} \cdot$ $\mathrm{L}^{-1}$ TRIS buffer solution $(\mathrm{pH}=8.5)$ containing $400 \mathrm{mg}$ DA, followed by vigorous stirring for $24 \mathrm{~h}$ to form poly(dopamine) (PDA) film on the $\mathrm{Pt} \mathrm{NPs} / \mathrm{SiO}_{2}$ particle. After centrifugated, washed with TRIS buffer solution and dried in vacuum oven at $60{ }^{\circ} \mathrm{C}$ overnight, PDA-coated Pt NPs $/ \mathrm{SiO}_{2}$ microspheres (PDA@Pt $\mathrm{NPs} / \mathrm{SiO}_{2}$ ) were obtained. After carbonized under nitrogen atmosphere at $800{ }^{\circ} \mathrm{C}$ for $2 \mathrm{~h}$, nitrogen-doped carbon layer-coated Pt NPs $/ \mathrm{SiO}_{2}$ (HNCMS@Pt NPs/ $/ \mathrm{SiO}_{2}$ ) microspheres were obtained. Finally, the silica core in $\mathrm{HNCMS} @ \mathrm{Pt} \mathrm{NPs} / \mathrm{SiO}_{2}$ microsphere was removed by $2 \mathrm{~mol} \cdot \mathrm{L}^{-1} \mathrm{HF}+8 \mathrm{~mol} \cdot \mathrm{L}^{-1} \mathrm{NH}_{4} \mathrm{~F}$ solution for $2 \mathrm{~h}$ and the obtained product was labeled as HNCMS@Pt NPs.

\subsection{Characterization and electrochemical measurements}

The morphology and structure of the prepared HNCMS@Pt NPs catalyst were characterized by scanning electron microscopy (SEM, JEOL JSM-6700, Japan), transmission electron microscopy (TEM, JEOL JEM-3010, Japan), and Raman spectroscopy (LabRAM-010, JY, Paris, France). X-ray diffraction (XRD) was performed on an X-ray diffractometer (D/MAX-RA diffractom- eter, Rigaku, Tokyo, Japan). Nitogen adsorption-desorption isotherms and Brunauer-Emmett-Teller (BET) surface area of the material were investigated by an ASAP 2020 automatic micropore and chemisorption analyzer (Micromeritics, Norctross, USA). The chemical states of N and Pt in HNCMS@Pt NPs were analyzed by X-ray photoelectron spectroscopy (XPS, Thermo Fisher Scientific K-Alpha 1063, UK) using Al $K_{\alpha}$ radiation. Pt content in HNCMS@Pt NPs was determined by inductively coupled plasmaatom emission spectroscopy (ICP-AES, IRIS Advantage 1000, Thermo Electron Massachusetts, USA).

For electrochemical investigation, glassy carbon (GC, $5 \mathrm{~mm}$ in diameter) electrode was polished with the slurry of 0.5 and 0.05 $\mu \mathrm{m}$ alumina successively and washed ultrasonically in ultra-pure water prior to use. The catalyst ink was prepared by dispersing the catalyst $(4 \mathrm{mg})$ in the mixture of ultra-pure water $(2 \mathrm{~mL})$ and ethanol $(2 \mathrm{~mL})$ by sonication. When a dark homogeneous dispersion was formed, $10 \mu \mathrm{L}$ of the ink was dropped onto the GC electrode using micro-syringe. For comparison, $20 \mu \mathrm{L}$ (or $5 \mu \mathrm{L}$ ) of the HNCMS@Pt NPs/ $\mathrm{SiO}_{2}$ (or the commercial 20\% (w) E-TEK $\mathrm{Pt} / \mathrm{C}$ ) was coated onto the GC electrode in order to keep the similar Pt loading mass on the electrode. After dried in air, the electrode was coated with $10 \mu \mathrm{L}$ of $0.05 \%$ (w) Nafion ethanol solution. The electrochemical performance of the catalyst was then evaluated by cyclic voltammetry and linear sweep voltammetry. All electrochemical measurements were performed on Autolab PGSTA12 (Eco Chemie B.V., Utrecht, the Netherlands) at room temperature in a conventional three-electrode glass cell with a platinum wire as the counter electrode and a $\mathrm{Ag} / \mathrm{AgCl} / \mathrm{saturated}$ $\mathrm{KCl}$ aqueous solution as the reference electrode.

\section{Results and discussion}

\subsection{Characterization of HNCMS@Pt NPs hybrids}

Fig.1(A-D) shows the SEM images of the $\mathrm{SiO}_{2}$ microspheres, PDA-wrapped Pt NPs/SiO ${ }_{2}, \mathrm{HNCMS} @ \mathrm{Pt} \mathrm{NPs} / \mathrm{SiO}_{2}$, and HNCMS@Pt NPs. From Fig.1A, it is noted that the diameter of $\mathrm{SiO}_{2}$
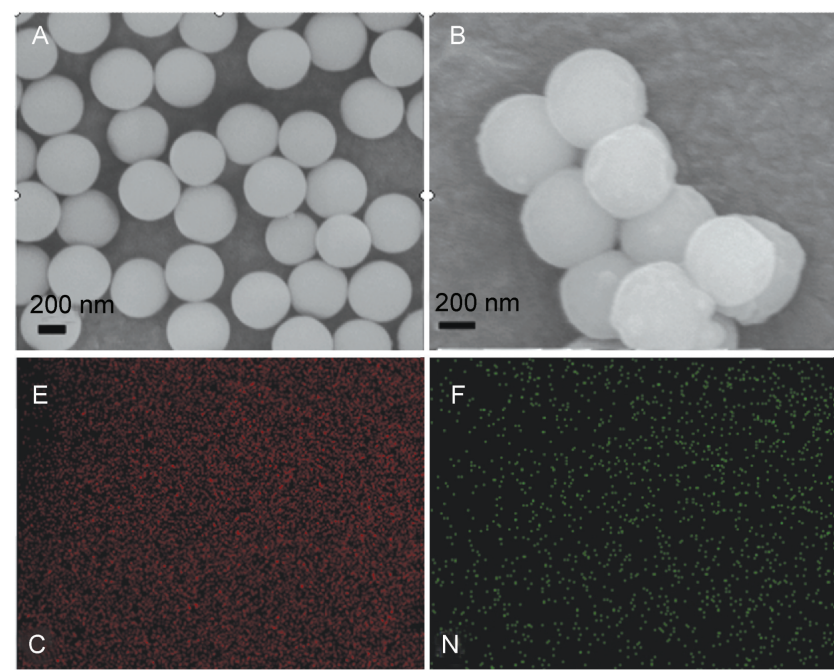
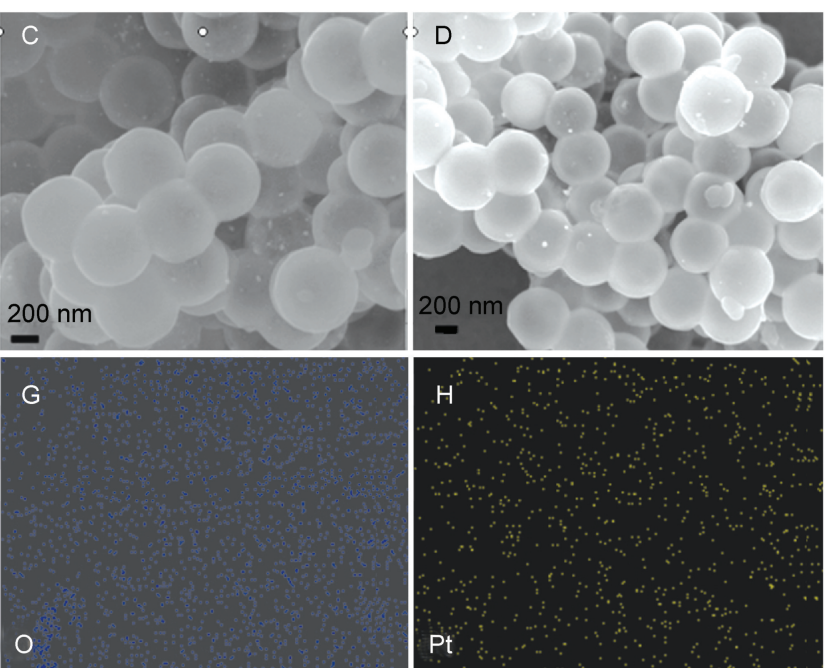

Fig.1 SEM images of $\mathrm{SiO}_{2}$ microspheres (A), PDA@Pt NPs/SiO $(\mathrm{B}), \mathrm{HNCMS} @ \mathrm{Pt} \mathrm{NPs} / \mathrm{SiO}_{2}$ (C), and HNCMS@Pt NPs (D); element mapping images of $\mathrm{C}(\mathrm{E}), \mathrm{N}(\mathrm{F}), \mathrm{O}(\mathrm{G})$, and Pt $(\mathrm{H})$ in the HNCMS@Pt NPs hybrids 
microspheres is about $500 \mathrm{~nm}$. PDA@Pt NPs $/ \mathrm{SiO}_{2}$ with diameter of about $580 \mathrm{~nm}$ can be observed in Fig.1B. From Fig.1(C, D), it is noted that the diameter of microspheres decreases to about 556 $\mathrm{nm}$ after the pyrolysis of PDA and no obvious change is observed for the diameter of microspheres before and after removal of $\mathrm{SiO}_{2}$ template. This indicates that the structure of the HNCMS@Pt NPs is stable and a good carbon replicate can be obtained based on the present method. The elemental mapping results shown in Fig.1(EH) confirm that the obtained HNCMS@Pt NPs hybrids are composed of $\mathrm{C}, \mathrm{N}, \mathrm{O}$, and Pt elements and each element distributes uniformly in HNCMS@Pt NPs hybrids.

Fig.2(A, B) displays the TEM images of Pt NPs@ $\mathrm{SiO}_{2}$ and HNCMS@Pt NPs/ $\mathrm{SiO}_{2}$ microspheres. As shown in Fig.2A, Pt NPs $(1-2 \mathrm{~nm})$ are uniformly dispersed on the $\mathrm{SiO}_{2}$ microspheres. From Fig.2B, HNCMS@Pt NPs/ $/ \mathrm{SiO}_{2}$ with diameter of about $556 \mathrm{~nm}$ can be observed and Pt NPs are uniformly distributed between the carbon layers and the $\mathrm{SiO}_{2}$ microspheres. This is confirmed clearly by the TEM image of HNCMS@Pt NPs shown in Fig.2C. It is noted from Fig.2C that HNCMS@Pt NPs hybrid has a structure of hollow core and carbon shell. The diameter of the hollow microspheres is about $556 \mathrm{~nm}$ and the thickness of carbon shell is around $28 \mathrm{~nm}$. Although the HNCMS@Pt NPs/SiO $\mathrm{Si}_{2}$ composites are carbonized at $800{ }^{\circ} \mathrm{C}$ and then followed by $\mathrm{HF}$ treatment to remove $\mathrm{SiO}_{2}$, Pt NPs are still uniformly dispersed in the inner surface of the HNCMSs and no obvious Pt NPs are exposed in the outer surface of the HNCMS@Pt NPs hybrids. The related highresolution TEM (HRTEM) image (the inset of Fig.2C) reveals that the lattice distance of the Pt NPs is $0.23 \mathrm{~nm}$, which is consistent with the $d$-spacing of the (111) plane of face-centered cubic $\mathrm{Pt}^{18}$. Furthermore, the size distribution is estimated to be mostly between 1-8 nm (Fig.2D) with an average diameter of about $4.4 \mathrm{~nm}$ through measuring the diameter of 200 Pt NPs in HNCMS@Pt NPs. The particle size of Pt NPs in the HNCMS@Pt NPs hybrids is much larger than that in Pt $\mathrm{NPs} @ \mathrm{SiO}_{2}$ hybrids and the commercial E-TEK Pt/C catalysts (at about $2 \mathrm{~nm})^{19}$, caused by high temperature calcination.

Fig.3A shows the XRD pattern of the HNCMS@Pt NPs hybrids. A broad diffraction peak at $2 \theta \approx 23^{\circ}$ is observed and should be assigned to (002) lattice plane of the hexagonal carbon, indicating the highly disordered or ungraphitized carbon structure under the carbonization temperature of $800{ }^{\circ} \mathrm{C}^{20}$. In addition, the diffraction peaks at $2 \theta$ around $39.7^{\circ}, 46.1^{\circ}$, and $67.7^{\circ}$ correspond to the $\operatorname{Pt}(111), \operatorname{Pt}(200)$, and $\operatorname{Pt}(220)$ facets, respectively ${ }^{21}$. The HNCMS@Pt NPs hybrids were further characterized by Raman spectroscopy and the corresponding results are shown in Fig.3B. There are two peaks centered at 1320 and $1579 \mathrm{~cm}^{-1}$. The peak at $1320 \mathrm{~cm}^{-1}$ ( $D$ band) is attributed to an $A_{\mathrm{gg}}$ mode of disordered graphite structure, and the peak at $1579 \mathrm{~cm}^{-1}$ ( $G$ band) corresponds to $E_{2 \mathrm{~g}}$ mode of graphite structure ${ }^{22}$. The intensity ratio of $D$ and $G$ bands $\left(I_{D} / I_{G}=1.09\right)$ reflects that the HNCMS shell in the HNCMS@Pt NPs hybrids has an amorphous carbon structure with a low graphitic crystallinity, which is consistent with the XRD results.

The porous texture of the HNCMS@Pt NPs hybrids were further investigated and the corresponding $\mathrm{N}_{2}$ adsorption-desorption isotherm and pore size distribution are shown in Fig.4.
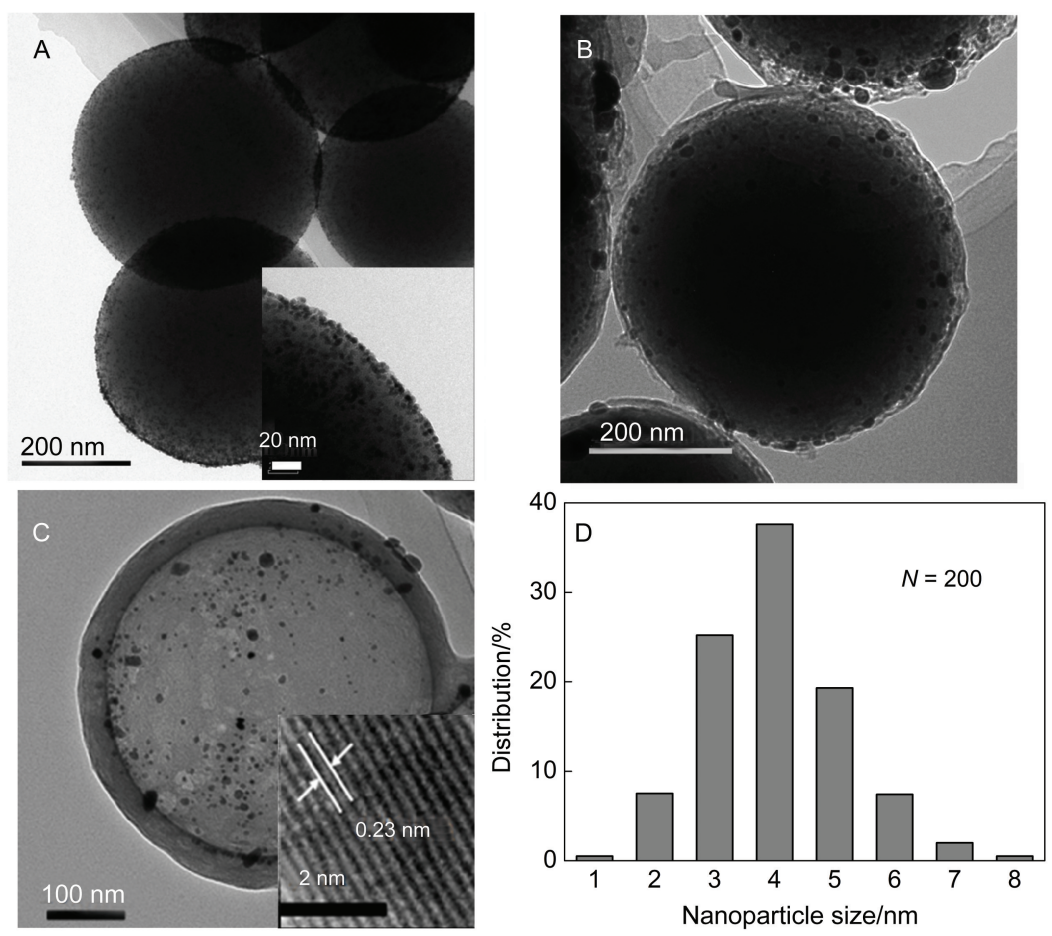

Fig.2 TEM images of Pt NPs/SiO $(\mathrm{A}), \mathrm{HNCMS} @ P t \mathrm{NPs} / \mathrm{SiO}_{2}$ (B), and HNCMS@Pt NPs (C); particle size of Pt NPs in the HNCMS@Pt NPs hybrids (D)

Insert in Fig.2A shows the TEM image of Pt NPs/ $\mathrm{SiO}_{2}$ at large magnification. Insert in Fig.2C shows the high-resolution TEM image of Pt NPs. 

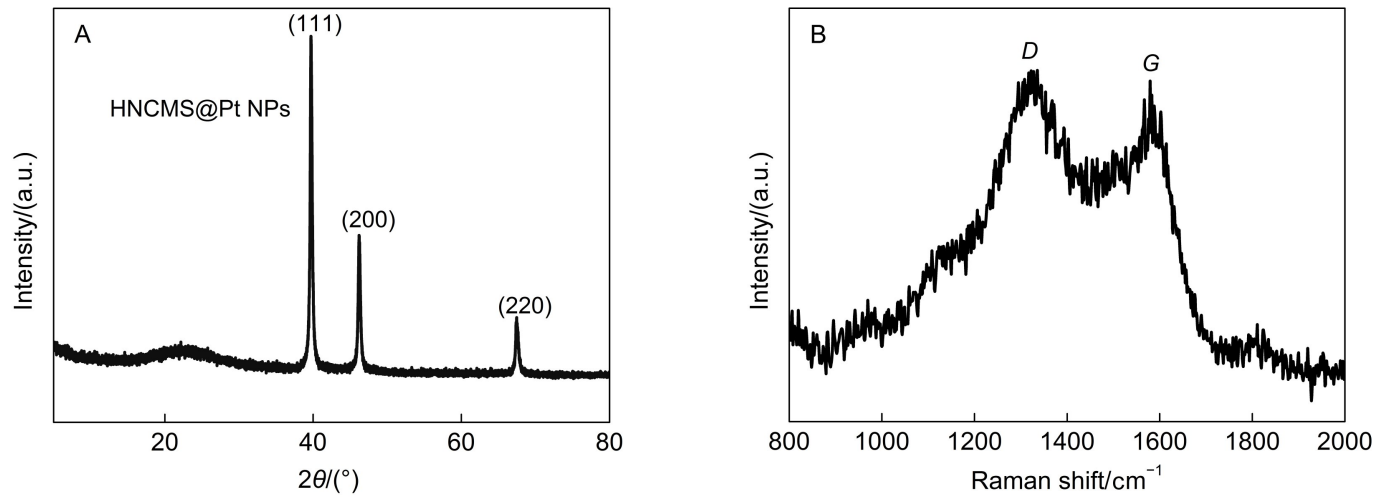

Fig.3 XRD pattern (A) and Raman spectrum (B) of HNCMS@Pt NPs
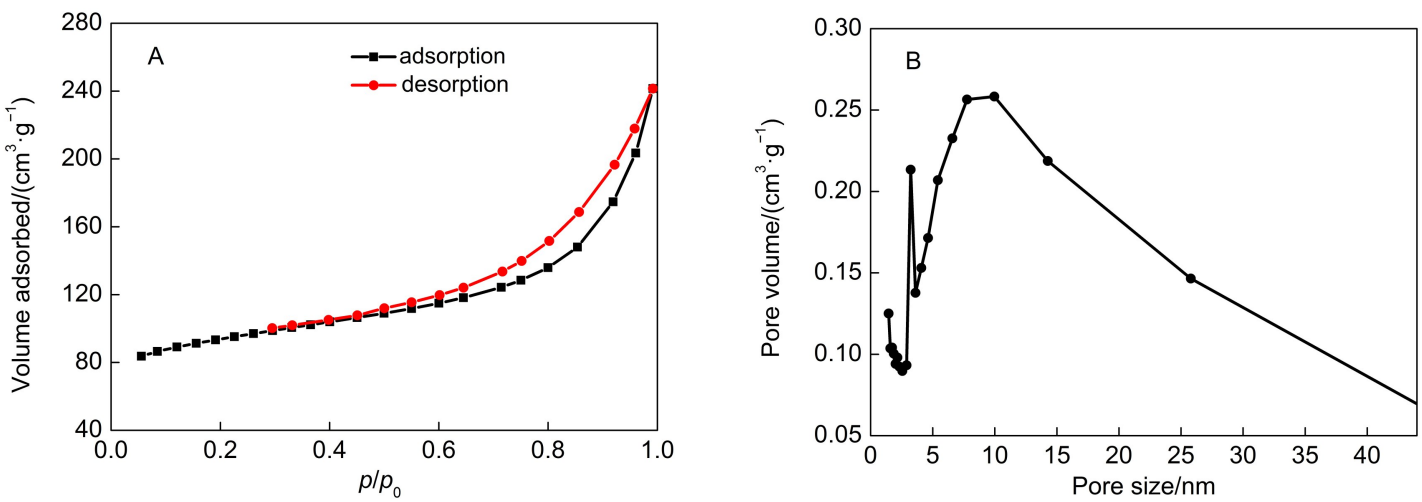

Fig.4 (A) Nitrogen adsorption-desorption isotherms and (B) the corresponding BJH pore size distribution of the HNCMS@Pt NPs hybrids

The Brunauer-Emmett-Teller (BET) specific surface area of the HNCMS@Pt NPs hybrids was measured and is about $301 \mathrm{~m}^{2} \cdot \mathrm{g}^{-1}$, which is higher than that of Vulcan XC-72 $\left(211 \mathrm{~m}^{2} \cdot \mathrm{g}^{-1}\right)^{23}$. The results in Fig.4A show a pseudo-type IV isotherm and a hysteresis loop, which corresponds to the mesoporous nature of the materials $^{24}$. From Fig.4B, it is noted that the pore size distribution (PSD) of the sample is centered at 3.2 and $8.6 \mathrm{~nm}$, calculated by the nitrogen desorption Barrett-Joyner-Halenda (BJH) method. Here, $3.2 \mathrm{~nm}$ should be the pore size of the HNCMS@Pt NPs hybrids, while $8.6 \mathrm{~nm}$ may be caused by the pores between the HNCMS@Pt NPs hybrids. It is well-known that mesoporous structure is favorable to the mass transfer of molecules and ions in aqueous electrolyte ${ }^{25}$. These results imply that $\mathrm{O}_{2}$ may transfer through the HNCMS shell and reach to the surface of Pt NPs, which increases the utilization efficiency of the catalysts in electrocatalytic processes.

The chemical states of Pt and N in the HNCMS@Pt NPs hybrids were investigated by XPS and Fig. 5 shows the related $\mathrm{N} 1 s$ and Pt $4 f$ high-resolution XPS spectra. From Fig.5A, the $\mathrm{N}$ content in the HNCMS@Pt NPs hybrids is estimated to be 5.77\% (atomic ratio, $x$ ) and the $\mathrm{N} 1 s$ spectrum can be divided into four types of peaks corresponding to the different chemical states of nitrogen: pyridinic $\mathrm{N}(398.3 \mathrm{eV})$, pyrrolic $\mathrm{N}(399.0 \mathrm{eV})$, quaternary $\mathrm{N}$ $(401.0 \mathrm{eV})$ and $\mathrm{N}$-oxides $(403.1 \mathrm{eV})^{26}$. The further quantitative analysis of $\mathrm{N} 1 s$ spectra reveals that the largest amount of $\mathrm{N}$ content in HNCMS@Pt NPs is present in the form of quaternary
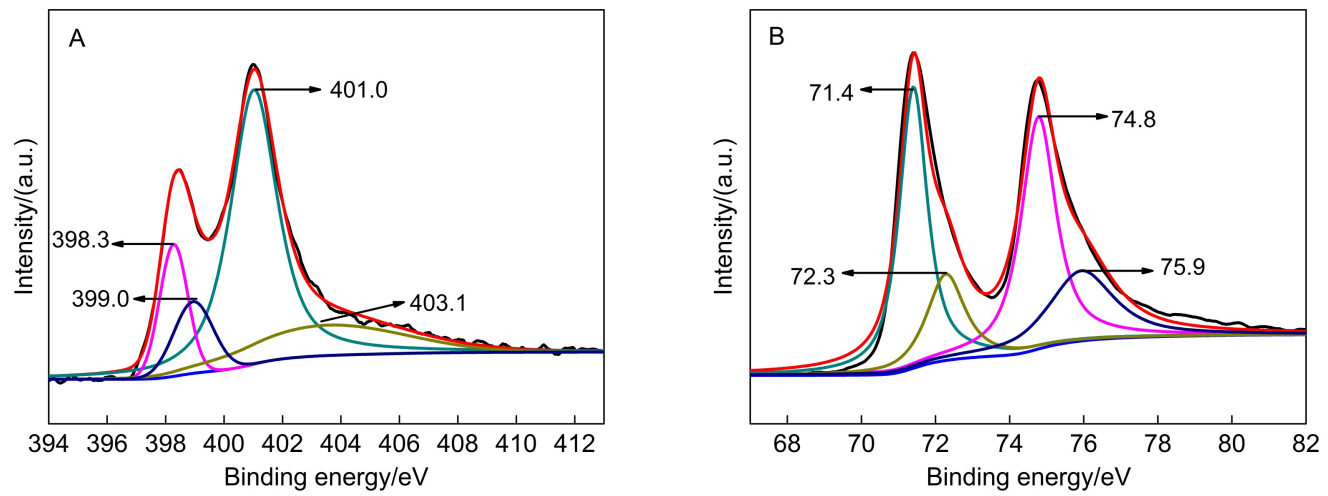

Fig.5 High-resolution XPS spectra of the (A) N $1 s$ and (B) Pt $4 f$ of HNCMS@Pt NPs hybrids 
$\mathrm{N}$ (about $56.5 \%(x)$ ), which is beneficial to the improved electrochemical activity of $\mathrm{N}$-doped carbon materials $\mathrm{s}^{27}$. This affords an additional advantage for HNCMS@Pt NPs to be employed as excellent ORR catalysts. On the other hand, from the spectrum of Pt $4 f$ (Fig.5B), two main peaks located at 71.4 and $74.8 \mathrm{eV}$ are attributed to metallic $\mathrm{Pt}$, while the two small peaks at 72.3 and $75.9 \mathrm{eV}$ can be classified as platinum oxide such as $\mathrm{Pt}(\mathrm{OH})_{2}$ and $\mathrm{PtO}^{28}$. This further indicates that metallic $\mathrm{Pt}$ should be the main species in the HNCMS@Pt NPs catalyst, which is also beneficial to ORR. In addition, the Pt content in the HNCMS@Pt NPs was measured by ICP-AES and is about $11.9 \%(w)$. This value is much higher than that in other methanol-tolerant oxygen reduction catalysts $^{13,14}$ implying that the developed HNCMS@Pt NPs hybrids should have promising application in practical DMFCs as the methanol-tolerant cathodic catalysts.

\subsection{Electrochemical properties of HNCMS@Pt NPs hybrids for ORR}

The electrocatalytic properties of HNCMS@Pt NPs for ORR have been investigated by linear sweep voltammetry (LSV) in $\mathrm{O}_{2}$ saturated $0.5 \mathrm{~mol} \cdot \mathrm{L}^{-1} \mathrm{H}_{2} \mathrm{SO}_{4}$ solution at $1600 \mathrm{r} \cdot \mathrm{min}^{-1}$ and the corresponding results are shown in Fig.6A. It is noted that the electrocatalytic activity of the HNCMS@Pt NPs electrocatalyst for ORR is much better than that of HNCMS@Pt NPs/ $\mathrm{SiO}_{2}$. This indicates clearly that the hollow structure plays an important role in the electroactivity of HNCMS@Pt NPs electrocatalyst for ORR, due to the reservoir-like effect of the hollow interior of HNCMS@Pt NPs electrocatalyst for $\mathrm{O}_{2}{ }^{29}$. On the other hand, it can also be obtained from Fig.6A that the electrocatalytic activity of the HNCMS@Pt NPs electrocatalyst for ORR is comparable to (or slightly better than) that of the comerical E-TEK Pt/C, although the particle size of Pt NPs in HNCMS@Pt NPs (about 4.4 $\mathrm{nm}$ ) is larger than that in E-TEK Pt/C (about $2.0 \mathrm{~nm}$ ). The onset potential of ORR on the HNCMS@Pt NPs electrocatalyst is slightly shifted in positive direction in comparison with that on the commercial E-TEK Pt/C.

To further investigate the ORR mechanism on the HNCMS@Pt NPs electrocatalyst, LSV investigation was carried out on a rotation disk electrode (glassy carbon, $5 \mathrm{~mm}$ ) in $\mathrm{O}_{2}$-saturated 0.5 $\mathrm{mol} \cdot \mathrm{L}^{-1} \mathrm{H}_{2} \mathrm{SO}_{4}$ solution at different rotation speed (from 225 to $\left.1600 \mathrm{r} \cdot \min ^{-1}\right)$. The electron transfer number $(n)$ per oxygen molecule involved in ORR can be calculated according to the Koutecky-Levich (K-L) plots $\left(I^{-1} v s \omega^{-1 / 2}\right)$ shown in Fig.6C $\mathrm{C}^{30}$. It is noted from Fig.6C that the K-L lines show good linearity and parallelism, suggesting that the electron transfer numbers of ORR at different potentials are similar. The electron-transfer numbers are calculated to be 3.61 at $0.20 \mathrm{~V}, 3.58$ at $0.25 \mathrm{~V}, 3.65$ at $0.30 \mathrm{~V}$, and 3.61 at $0.35 \mathrm{~V}$, respectively, suggesting that a four-electrontransfer process of ORR occurs mainly at the HNCMS@Pt NPs catalysts.

The durability of the electrocatalyst is of great importance in practical application. Therefore, the long-term stability of the HNCMS@Pt NPs catalyst was evaluated by a standard accelerated durability testing $(\mathrm{ADT})^{31,32}$, which was performed by potential cycling (2000 cycles) from 0.2 to $0.8 \mathrm{~V}$ at a scan rate of $100 \mathrm{mV}$. $\mathrm{s}^{-1}$ in $\mathrm{O}_{2}$-saturated $0.5 \mathrm{~mol} \cdot \mathrm{L}^{-1} \mathrm{H}_{2} \mathrm{SO}_{4}$ solution. Before and after ADT, the related LSV investigation towards ORR was carried out in $\mathrm{O}_{2}$-saturated $\mathrm{H}_{2} \mathrm{SO}_{4}$ solution at a scan rate of $10 \mathrm{mV} \cdot \mathrm{s}^{-1}$. For comparison, the long-term stability of the commercial E-TEK Pt/ $\mathrm{C}$ catalyst was also evaluated under the same conditions. From Fig.7, it is noted that a small negative shift of the LSV curve occurs on the HNCMS@Pt NPs catalyst and the half-wave potential of ORR on the HNCMS@Pt NPs catalyst shifts negatively about $27 \mathrm{mV}$ after ADT. However, for the commercial E-TEK Pt/
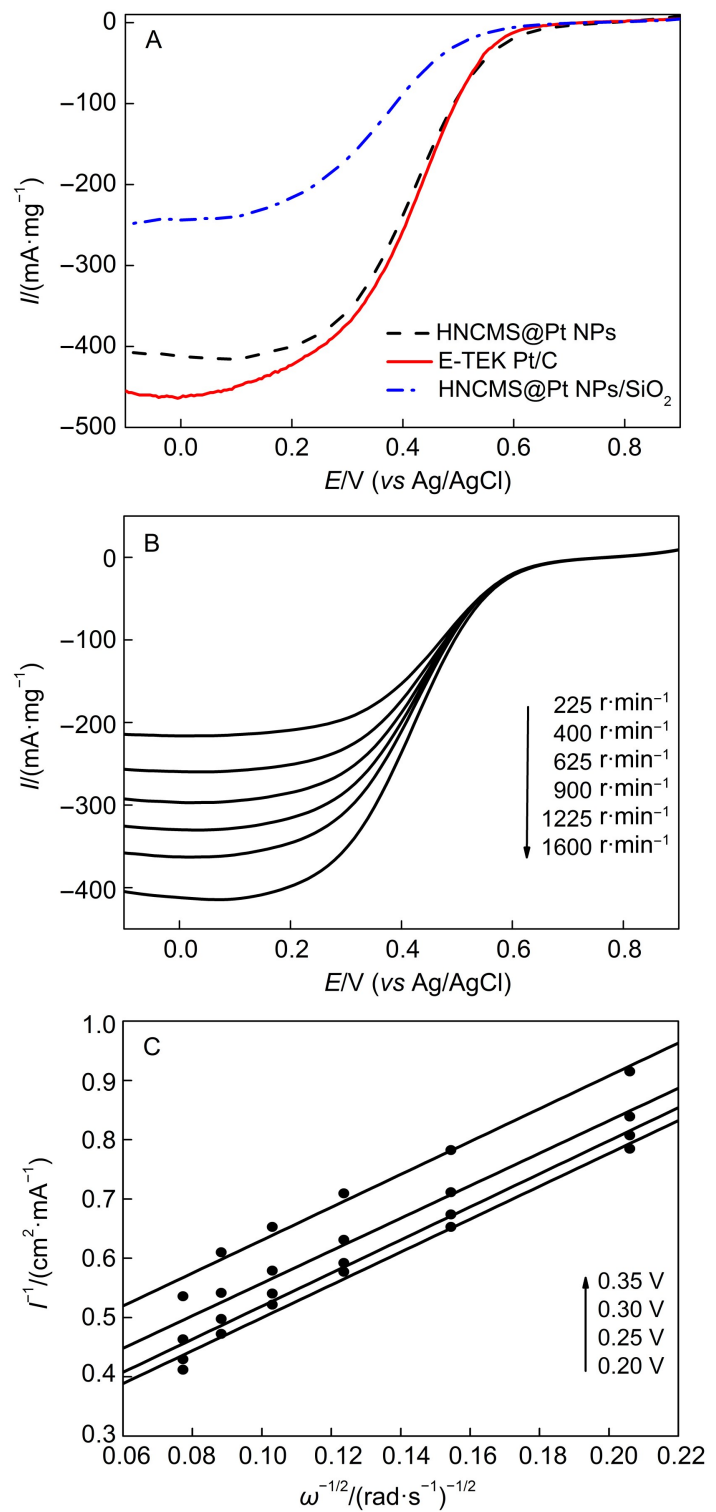

Fig.6 (A) Linear sweep voltammograms of HNCMS@Pt/SiO HNCMS@Pt NPs, E-TEK Pt/C in $\mathrm{O}_{2}$-saturated $0.5 \mathrm{~mol} \cdot \mathrm{L}^{-1} \mathrm{H}_{2} \mathrm{SO}_{4}$ solution with a sweep rate of $10 \mathrm{mV} \cdot \mathrm{s}^{-1}$ and a rotation rate of 1600 $\mathbf{r} \cdot \mathbf{m i n}^{-1}$; (B) linear sweep voltammograms of HNCMS@Pt NPs in $\mathrm{O}_{2}$-saturated $0.5 \mathrm{~mol} \cdot \mathrm{L}^{-1} \mathrm{H}_{2} \mathrm{SO}_{4}$ with a sweep rate of $10 \mathrm{mV} \cdot \mathrm{s}^{-1}$ and different rotation rates $\left(225-1600 \mathrm{r} \cdot \mathrm{min}^{-1}\right)$; (C) KouteckyLevich lines of HNCMS@Pt NPs at various potentials corresponding to the figure $\mathrm{B}$ 


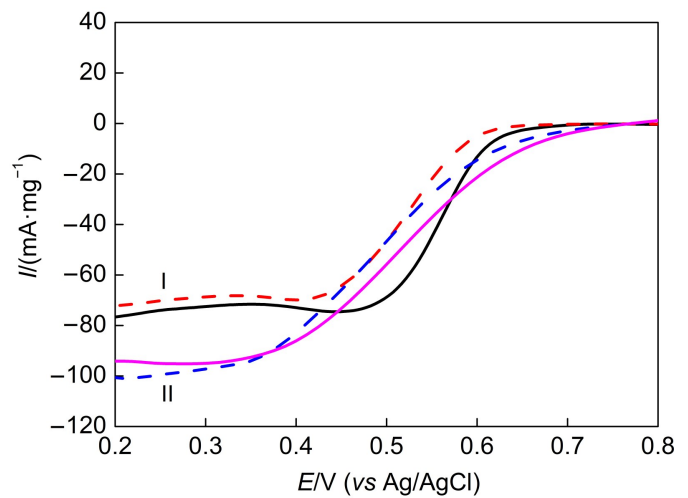

Fig.7 Linear sweep voltammograms of ORR on the E-TEK Pt/C (I) and HNCMS@Pt NPs (II) catalysts in $\mathrm{O}_{2}$-saturated $0.5 \mathrm{~mol} \cdot \mathrm{L}^{-1}$ aqueous $\mathrm{H}_{2} \mathrm{SO}_{4}$ before (-) and after (----) ADT

C catalyst, a big negative shift of the LSV curve occurs after ADT and the half-wave potential shifts negatively about $52 \mathrm{mV}$. These clearly indicate that the HNCMS@Pt NPs catalyst possesses good long-term stability for ORR, which may result from the encapsulation of Pt NPs by carbon layer of HNCMS and the coordination action between Pt NPs and N atoms in $\mathrm{HNCMS}^{8}$.

For DMFCs, it is well known that methanol can easily cross over from the anode to the cathode through the Nafion membrane, and will deteriorate the performance of the cathode. The methanoltolerant property is another important parameter of the cathodic catalyst in DMFCs. Here, the crossover effects of methanol on ORR for both HNCMS@Pt NPs and E-TEK Pt/C catalysts were evaluated in Ar-saturated $0.5 \mathrm{~mol} \cdot \mathrm{L}^{-1} \mathrm{H}_{2} \mathrm{SO}_{4}, \mathrm{O}_{2}$-saturated 0.5 $\mathrm{mol} \cdot \mathrm{L}^{-1} \mathrm{H}_{2} \mathrm{SO}_{4}$, and $\mathrm{O}_{2}$-srturated $0.5 \mathrm{~mol} \cdot \mathrm{L}^{-1} \mathrm{H}_{2} \mathrm{SO}_{4}$ with $0.5 \mathrm{~mol} \cdot$ $\mathrm{L}^{-1}$ methanol. It is noted that the current density of ORR increases obviously when the potential is below 0.64 V on the HNCMS@Pt NPs catalyst in $\mathrm{O}_{2}$-saturated solution and no obvious change can be observed when methanol is added (Fig.8A). However, from Fig.8B, it is noted that the ORR peak at the E-TEK Pt/C catalyst disappears and two typical oxidation peaks of methanol can be clearly observed at about 0.64 and $0.41 \mathrm{~V}$, respectively, when the electrolyte solution is changed from $\mathrm{O}_{2}$-saturated 0.5 $\mathrm{mol} \cdot \mathrm{L}^{-1} \mathrm{H}_{2} \mathrm{SO}_{4}$ aqueous solution to $\mathrm{O}_{2}$-saturated $0.5 \mathrm{~mol} \cdot \mathrm{L}^{-1}$ $\mathrm{H}_{2} \mathrm{SO}_{4}+0.5 \mathrm{~mol} \cdot \mathrm{L}^{-1}$ methanol aqueous solution. This indicates that HNCMS@Pt NPs catalyst has remarkably better ability to avoid crossover effect than E-TEK Pt/C. Furthermore, no methanol oxidation peaks can be observed on the HNCMS@Pt NPs catalyst (Fig.8C) and the current density at $0.5 \mathrm{~V}$ remains $81 \%$ of the initial value (Fig.8D) even after 500 potential cycles in $\mathrm{O}_{2}-$ saturated $\mathrm{H}_{2} \mathrm{SO}_{4}$ electrolyte containing $0.5 \mathrm{~mol} \cdot \mathrm{L}^{-1}$ methanol. These indicate that the HNCMS@Pt NPs catalyst has good methanol-tolerant property and durability. This may result from that the thick and mesoporous carbon shell of HNCMS makes the embedded Pt NPs be easily accessible to $\mathrm{O}_{2}$ molecules but greatly obstructive to methanol crossover ${ }^{12}$.
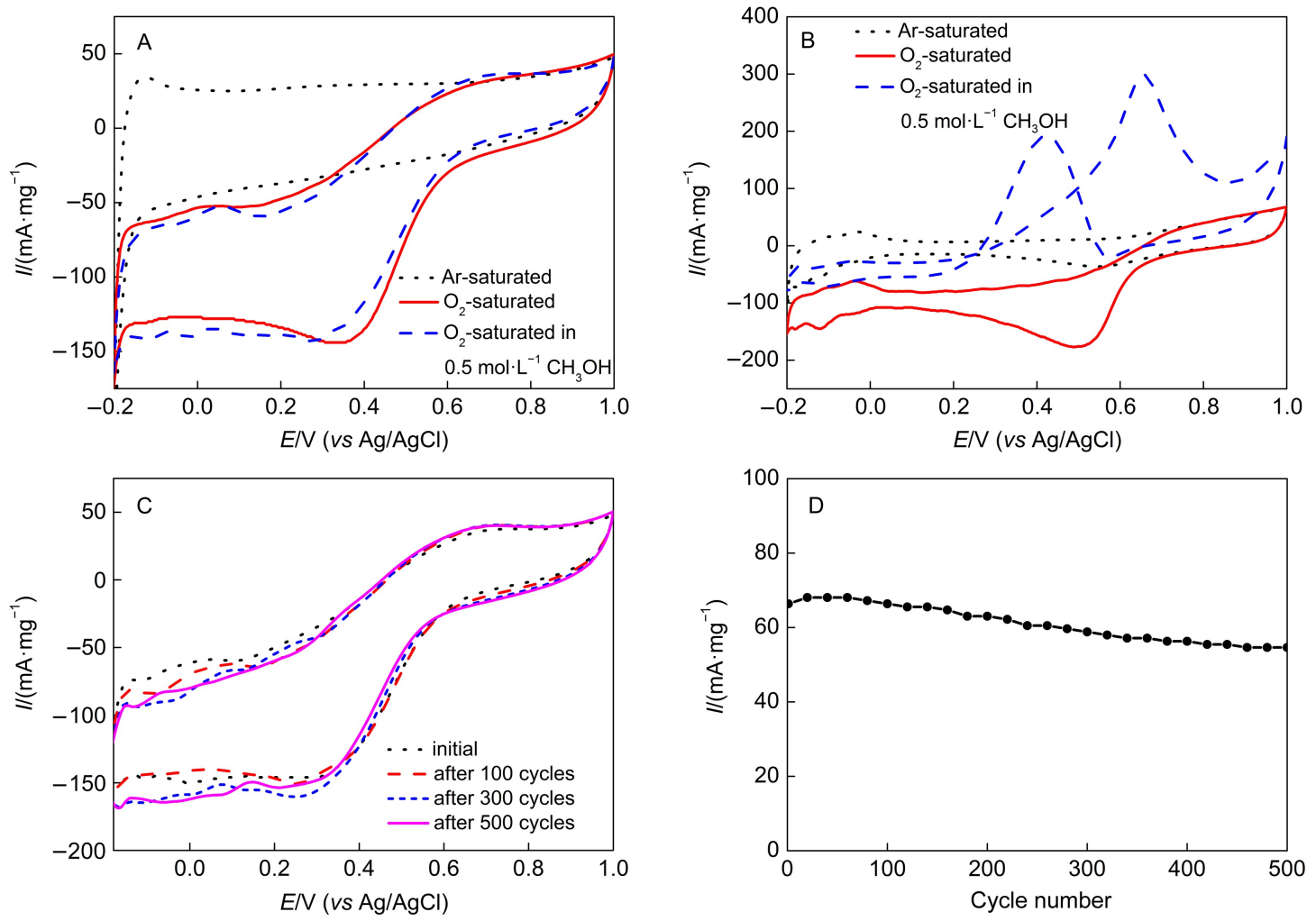

Fig.8 Cyclic voltammograms of (A) HNCMS@Pt NPs and (B) commercial E-TEK Pt/C on a glass carbon electrode in Ar-saturated 0.5 $\mathrm{mol} \cdot \mathrm{L}^{-1} \mathrm{H}_{2} \mathrm{SO}_{4}, \mathrm{O}_{2}$-saturated $0.5 \mathrm{~mol} \cdot \mathrm{L}^{-1} \mathrm{H}_{2} \mathrm{SO}_{4}, \mathrm{O}_{2}$-saturated $0.5 \mathrm{~mol} \cdot \mathrm{L}^{-1} \mathrm{H}_{2} \mathrm{SO}_{4}+0.5 \mathrm{~mol} \cdot \mathrm{L}^{-1}$ methanol at a sweep rate of $50 \mathrm{mV} \cdot \mathrm{s}^{-1}$; (C) cycling performance of HNCMS@Pt NPs in $\mathrm{O}_{2}$-saturated $0.5 \mathrm{~mol} \cdot \mathrm{L}^{-1} \mathrm{H}_{2} \mathrm{SO}_{4}+0.5 \mathrm{~mol} \cdot \mathrm{L}^{-1}$ methanol at a sweep rate of $50 \mathrm{mV} \cdot \mathrm{s}^{-1}$; (D) stability of HNCMS@Pt NPs over 500 cycles of ORR in $\mathrm{O}_{2}$-saturated $0.5 \mathrm{~mol} \cdot \mathrm{L}^{-1} \mathrm{H}_{2} \mathrm{SO}_{4}+0.5 \mathrm{~mol} \cdot \mathrm{L}^{-1} \mathrm{methanol}$ 


\section{Conclusions}

Based on a hard template method, a new methanol-tolerant electrocatalyst for ORR, HNCMS@Pt NPs hybrid, has been developed. Here, $\mathrm{NH}_{2}$-functionalized $\mathrm{SiO}_{2}$ microsphere was used as a template and dopamine was used as carbon and nitrogen sources. The obtained HNCMS@Pt NPs catalyst has hollow core, thick Ndoped carbon shell with mesoporous structure, and small Pt NPs on the inner surface of HNCMS. These features make the HNCMS@Pt NPs catalyst exhibit good electrocatalytic activity, high stability, and excellent methanol-tolerant property towards ORR. It is worthy to note that the unique microsphere morphology and mesoporous structure of HNCMS@Pt NPs makes the encapsulated Pt NPs be easily accessible to $\mathrm{O}_{2}$ molecules but greatly obstructive to methanol crossover. Importantly, the Pt loading mass in the developed HNCMS@Pt NPs catalyst is much higher than that in other reported methanol-tolerant oxygen reduction catalysts, implying that the developed HNCMS@Pt NPs catalyst has promising application in practical DMFCs as the methanoltolerant cathodic catalysts. This work provides an effective approach to develop ORR catalysts with high activity, stability, and methanol-tolerant property.

\section{References}

(1) Wang, H.; Liang, J.; Zhu, L.; Peng, F.; Yu, H.; Yang, J. Fuel Cells 2010, 10 (1), 99. doi: 10.1002/fuce.200900112

(2) Li, L.; He, X. L.; Qin, T.; Dai, F. T.; Zhang, X. H.; Chen, J. H. Acta Phys. -Chim. Sin. 2015, 31 (5), 927. [李 丽, 何小丽, 覃 涛, 戴富涛, 张小华, 陈金华.物理化学学报, 2015, 31 (5), 927.] doi: 10.3866/PKU.WHXB201503241

(3) Wang, C.; Kang, J. X.; Wang, L. L.; Chen, T. W.; Li, J.; Zhang, D. F.; Guo, L. Acta Phys. -Chim. Sin. 2014, 30 (4), 708. [王 纯, 康建新, 王利利, 陈庭文, 李 杰, 张东风, 郭 林. 物理化学学 报, 2014, 30 (4), 708.] doi: 10.3866/PKU.WHXB201401222

(4) Cui, Z. M.; Chen, H.; Zhao, M. T.; Marshall, D.; Yu, Y. C.; Abruna, H.; DiSalvo, F. J. J. Am. Chem. Soc. 2014, 136 (29), 10206. doi: 10.1021/ja504573a

(5) Cui, Y.; Kuang, Y. J.; Zhang, X. H.; Liu, B.; Chen, J. H. Acta Phys. -Chim. Sin. 2013, 29 (5), 989. [崔颖, 匡尹杰, 张小华, 刘 博, 陈金华. 物理化学学报, 2013, 29 (5), 989.] doi: 10.3866/PKU.WHXB201303121

(6) Zhou, Y.; Chu, Y. Q.; Liu, W. M.; Ma, C. A. Acta Phys. -Chim. Sin. 2013, 29 (2), 287. [周 阳, 褚有群, 刘委明, 马淳安. 物理化学学报, 2013, 29 (2), 287.] doi: 10.3866/PKU. WHXB201211261

(7) Yang, W. X.; Liu, X. J.; Yue, X. Y.; Jia, J. B.; Guo, S. J. J. Am. Chem. Soc. 2015, 137 (4), 1436. doi: 10.1021/ja5129132

(8) Oh, J. G.; Lee, C. H.; Kim, H. Electrochem. Commun. 2007, 9 (10), 2629. doi: 10.1016/j.elecom.2007.08.019

(9) Lee, K.; Savadogo, O.; Ishihara, A.; Mitsushima, S.; Kamiya, N.; Ota, K. J. Electrochem. Soc. 2006, 153 (1), A20. doi: $10.1149 / 1.2128101$

(10) Ozenler, S. S.; Kadırgan, F. J. Power Sources 2006, 154 (2),
364. doi: 10.1016/j.jpowsour.2005.10.031

(11) Pylypenko, S.; Mukherjee, S.; Olson, T. S.; Atanassov, P. Electrochim. Acta 2008, 53 (27), 875. doi: 10.1016/j. electacta.2008.05.047

(12) Wen, Z. H.; Liu, J.; Li, J. H. Adv. Mater. 2008, 20 (4), 743 doi: 10.1002/adma.200701578

(13) Wu, Z. X.; Lv, Y. Y.; Xia, Y. Y.; Webley, P. A.; Zhao, D. Y. J. Am. Chem. Soc. 2012, 134 (4), 2236. doi: 10.1021/ja209753w

(14) Guo, X.; Li, L.; Zhang, X. H.; Chen, J. H. ChemElectroChem 2015, 2 (3), 404. doi: 10.1002/celc.v2.3

(15) Dai, Y. H.; Jiang, H.; Hu, Y. J.; Fu, Y.; Li, C. Z. Ind. Eng. Chem. Res. 2014, 53 (8), 3125. doi: 10.1021/ie403950t

(16) Zhang, C.; Xu, L.; Shan, N.; Sun, T.; Chen, J.; Yan, Y. ACS Catal. 2014, 4 (6), 1926. doi: 10.1021/cs500107t

(17) Galeano, C.; Meier, J. C.; Soorholtz, M.; Bongard, H.; Baldizzone, C.; Karl, J. J. ACS Catal. 2014, 4 (11), 3856. doi: $10.1021 / \operatorname{cs} 5003492$

(18) Huang, Y. Q.; Huang, H. L.; Gao, Q. Z.; Gan, C. F.; Liu, Y. J. Electrochim. Acta 2014, 149, 34. doi: 10.1016/j. electacta.2014.10.102

(19) Zhang, X. H.; Zhong, J. D.; Yu, Y. M.; Zhang, Y. S.; Liu, B.; Chen, J. H. Acta Phys. -Chim. Sin. 2013, 29 (6), 1297. [张小华, 钟金娣, 于亚明, 张云松, 刘 博, 陈金华. 物理化学学报, 2013, 29 (6), 1297.] doi: 10.3866/PKU.WHXB201304011

(20) Cheng, J. L.; Wang, Y.; Teng, C.; Shang, Y. J.; Ren, L. B.; Jiang, B. W. Chem. Eng. J. 2014, 242, 285. doi: 10.1016/j. cej.2013.12.089

(21) Li, Q.; Pan, H. Y.; Higgins, D.; Cao, R. G.; Zhang, G. Q.; Lv, H. F.; Wu, K. B.; Cho, J.; Wu, G. Small 2015, 11 (12), 1443. doi: 10.1002/smll.v11.12

(22) Lian, S. Y.; Ming, H.; Huang, H.; Kang, Z. H.; Liu, Y. Mater. Res. Bull. 2012, 11 (47), 3336. doi: 10.1016/j. marerresbull.2012.07.029

(23) Ficicilar, B.; Bayrakceken, A.; Eroglu, I. Int. J. Hydrog. Energy 2010, 35 (18), 9924. doi: 10.1016/j.ijhydene.2009.11.016

(24) Ding, B.; Yuan, C. Z.; Shen, L. F.; Xu, G. Y.; Nie, P.; Zhang, X. G. Chem. Eur. J. 2013, 19 (3), 1013. doi: 10.1002/ chem. 201202127

(25) Liang, C. D.; Li, Z. J.; Dai, S. Angew. Chem. Int. Ed. 2008, 47 (20), 3696. doi: 10.1002/anie.200702046

(26) Pachfule, P.; Dhavale, V. M.; Kandambeth, S.; Kurungot, S.; Banerjee, R. Chem. Eur. J. 2013, 19 (3), 974. doi: 10.1002/ chem. 201202940

(27) Wang, H. G.; Wu, Z.; Meng, F. L.; Ma, D. L.; Huang, X. L.; Wang, L. M.; Zhang, X. B. ChemSusChem 2013, 6 (1), 56. doi: $10.1002 /$ cssc. 201200680

(28) Guo, Y. X.; He, J. P.; Wang, T.; Xue, H. R.; Hu, Y. Y.; Li, G. X.; Tang, J.; Sun, X. J. Power Sources 2011, 196 (22), 9299. doi: 10.1016/j.jpowsour.2011.07.073

(29) Chang, K. W.; Lim, Z. Y.; Du, F. Y.; Yang, Y. L.; Chang, C. H.; Hu, C. C.; Lin, H. P. Diamond Relat. Mater. 2009, 18 (2), 448 
doi: 10.1006/j.diamond.2008.10.003

(30) Li, S. S.; Lv, J. J.; Teng, L. N.; Wang, A. J.; Chen, J. R.; Feng, J. J. ACS Appl. Mater. Interfaces 2014, 6 (13), 10549. doi: 10.1021/am502148z

(31) Chaikittisilp, W.; Torad, N. L.; Li, C. L.; Imura, M.; Suzuki, N.;
Ishihara, S.; Ariga, K.; Yamauchi, Y. Chem. Eur. J. 2014, 20 (15), 4217. doi: 10.1002/chem.201304404

(32) Lang, X. Y.; Han, G. F.; Xiao, B. B.; Gu, L.; Yang, Z. Z.; Wen, Z.; Zhu, Y. F.; Zhao, M.; Li, J. H.; Jiang, Q. Adv. Funct. Mater. 2015, 25 (2), 230. doi: 10.1002/adfm.v25.2 